whatever is produced. This points conclusively to oxidation as the cause of the phenomenon.

We may here remark that this conclusion agrees with the results of the recent observations of $M$. Chastaing ${ }^{1}$ upon a number of organic bodies, which he found to be oxidised under the influence of light.

As regards our oxalic acid, we have also determined that the oxidation in this instance is probably of the hydrogen and not of the carbon of the molecule.

From analogy and from direct experiment we believe that the mode in which light injuriously affects the organisms with which our investigation deals, is neither more nor less than a gradual oxidation of their living bioplasm, similar to the oxidation of the comparatively simple molecule of oxalic acid.

There is a lingering belief in the minds of many that matter which is endowed with life can by its "vital resistance" the more endure and survive the effect of injurious influences. This belief, derived, perhaps, like many others from a misapprehension of the indirect for the direct and from a misapplication of analogies, has no support from our experiments. On the contrary, we have met with results which are best explained by the consideration that bioplasm is matter of the utmost complexity and instability of constitution, ever-changing and most instable when the vital forces are at their full. We believe, in a word, that instability of this life-stuff is a predisposing cause for the destructive action of light, while in its stabler conditions it is more resistant.

We wish to keep this note within the limits of brevity, and will only remark in conclusion that, since the organisms which have been the subject of our work may be regarded as "lifeunits," well fitted by their tenuity for the demonstration of the action of sunlight upon the "physical basis" of their life, we may reasonably expect, and, indeed, may see, that this action is not limited to these special cases. We have chosen, therefore, in the heading of these remarks, to indicate the wider field of their application, but we by no means wish to imply that the relations of light to bioplasm are in all cases so simple.

\section{UNIVERSITY AND EDUCATIONAL INTELLIGENCE}

AT the Graduation Ceremonial in Medicine and Law in connection with the University of Edinburgh held on August $\mathrm{x}$ the honorary degree of ILL.D. was conferred on James Risdon Bennett, M.D. Edinburgh, F.R.S., President of the Royal College of Physicians, Londou, Sir Joseph Fayrer, M.D. Edin burgh, K.C.S.I., F.R.S., John Richard Green, M.A. Oxon, Joseph Lister, M.B. London, F.R.S., lately Professor of Clinical Surgery in the University of Edinburgh, and now of King's College, London.

AT the annual meeting of the Council of the Royal School of Mines the prizes were awarded as follows :- The two Royal Scholarships, of $15 l$. each, for first year's students, to Mr. R. G. Scott and Mr. W. Cross; the Royal Scholarship, of $25 l$., to Mr. R. Lancaster; the Edward Forbes medal and prize of books, to Mr. P. F. Frankland; the De la Beche medal and prize of books, to Mr. F. G. Mills; the Murchison medal and prize of books, to $\mathrm{Mr}$. M. Terrero; and an extra medal to Syed Ali.

Mrs. Catherine Dauntesey Foxten has bequeathed to Owens College, Manchester, the sum of $5,000 l$, to found two scholarships, one Legal and the other Medical.

WORK has been commenced on the extensive edifices of the new Berlin Polytechnic, which is to be situated a short distance out of the city at Charlottenburg. Five years are expected to elapse before the completion of this much-needed institution.

THE city of Lille has received from the French Department of Education the sum of 50,000 francs to assist in the foundation of a medical school.

THE Imperial ukase amnouncing the foundation of the new Siberian University states that it shall number four faculties, the medical, the legal, the historico-philosophical, and the physico mathematical. Orders have been issued for the prompt con struction of the edifices, towards the expense of which the provincial government of Tomsk has already appropriated 250,000 roubles-about $35,000 l$.

$$
\text { I Ann. de Chinn. et de Phys., } 5 \text { ser. t. xi. }
$$

\section{SCIENTIFIC SERIALS}

Kosmos, April.-On life in Kosmos, by Carl du Prel, discussing possibilities of life in other worlds than ours. - The kingdom Protista, first part, by E. Haeckel.-On the physiology of the new-born, by M. Preyer. Part I : On hearing and sight.On the nests and gardens of Amblyornis inornata, or, rather, theories about them, by O. Beccari.-The sway of ceremonial, by Herbert Spencer. Part 4: On presents. - The discontinuance of human sacrifices, by E. Krause.

May.-The kingdom Protista, by E. Haeckel, describing Amceba, Protococcus, Euglena, Flagellata, Volvocina, Noctiluca, Infusoria, Acineta, Rhizopods, Foraminifera, and Radiolaria; forty-one excellent woodcuts.-On the physiology of the newly. born, by M. Preyer; on smell and taste.-The animal king. dom, as regards similarity of adaptations, by W. von Reich. enau.-The sway of ceremonial, by Herbert Spencer : On marks of honour.--Sexual selection ir plants, by W. Focke.

June.-Contribution to experimental æsthetics, by Rudolf Redtenbacher, pursuing Fechner's researches and discussing his results, analysing the causes of pleasure as regards the shapes and textures of flat surfaces, as well as of crystals.--Ernst Haeckel continues his popular articles entitled "The Kingdom Protista." He diverges very much into theory as usual, expounding his doctrine that the true animal kingdom is defined by the formation of a gastrula in its embryonic stage. On the side of phylogeny he considers the protista ascended to true animalism by becoming parasites.-Fritz Miiller describes the queens of the Meliponx, investigated in Brazil. He finds in four species the queens, or in some cases the parthenogenetic females, extraordinarily alike, while the males and workers are very different.-Herbert Spencer's sixth paper on the sway of ceremonial deals with forms of address; these articles are extracted from the future second volume of "Sociology."

Zeilschrift für wissenschaftliche Zoologie, vol. xxx. part 4.On the origin of the sexual products in hydroida, by $\mathrm{J}$. Ciamician; two plates of tubularia and endendrium.-Further contribution on the genus analges or dermaleichens (crustacean), by G. Haller; three plates.-On the structure of Reniera semitubulosa (sponge), by E. Keller; two plates.-On the structure of the Malpighian vessels of insects, by E. Schindler; 74 pages, three plates.

Vol, xxx., supplement, part 2.-Anatomical and zoological observations on the amphipods and isopods, by F. Leydig; fifty pages, four plates.-On the development of the testes and the alternation of generations in the salpæ, by W. Salensky.--On a mathematical method in zoology, illustrated from the acarida, by P. Kramer. - The reproductive organs of some ectoparasitic trematodes, by Carl Vogt; four plates, thirty-seven pages.On the movements of "flying fish" through the air, by KarI Möbius; one plate, forty pages; giving an account of all observations on the movements of these fish, the anatomical structures on which they depend, and the way in which the mechanism works.- Studies of the freshwater fauna of Switzerland, by F. A. Forel. He distinguishes the characters of the littoral, the pelagic, and the deep-sea fauna of Lake Leman; discusses the relations between the present fauna and that of recent geological periods, and the migrations of species; and concludes that the lacustrine fauna of the subalpine waters has entered by migration since the glacial period; that the littoral fauna has come from other lakes of other lands; the pelagic fauna from forms already differentiated as such before migration and the deep fauna by modification from the littoral.-On muddwelling cladocera, by W. Kurz; one plate, eighteen pages.

Vol. xxx., supplement, part 3.-On the early embryonic development of Tendra zostericola, by W. Repiachoff, one plate.-On the comet-forms of star-fishes, with a discussion of the phylogeny of the echinodermata, by E. Haeckel, one plate.-Contributions on protozoa, by A. Schneider : cn actinosphœrium; on development of miliola; on trichosphærium and chlamydomonas, one plate.-On the form and signification of organic muscle-cells, by W. Flemming. The author believes he has discovered the development of unstriped muscle-cells in Salamandra maculata out of connective tissue cells, one plate.-On the anatomy of the entomostracan Limnadia hermanni, by F. Spangenberg.-- Studies on the history of the Polish Tur, by A. Wrzesniowsli. In this exhaustive paper of sixty pages all the historical references are examined, and most interesting woodcuts copied from representations of two animals are given. The conclusion is that two of the Bovida 
remained extant in Poland to comparatively recent times, viz., Bos primigenizts and Bison europazs, and that the former was the last to die out, in the beginning of the seventeenth century. -On the unity of the structure of the brain in the different orders of insects, by J. H. L. Flögel, illustrated by two plates of capital photographic reproductions of microtome-sections, thirty. seven pages.-On Archigetes sieboldi, a sexual cestode-nurse, by R. Leuckart.-The epiphysis on the brain of :plagiostomes, by E. Ehlers, illustrated by two plates from Raia clavata and Acantrias vulgaris.

Bulletin de l'Académie Royale de Belgique, No. 5, 1878.This number contains a memoir by M. Firiket, treating of geological and chemical phenomena which have altered the rocks of an important metalliferous region in the province of Liége. The first part refers to the silurian fault and the metalliferous veins of the Champ d'Oiseaux; the second to the constitution and course of beds of oligiste; and the third to epigenic transformation of oolithic oligiste into siderite, in contact with a vein of pyrites (a propos of metalliferons veins of the mine of Landenne).-M. Spring, having conceived some doubts as to the existence of pentathionic acid, has examined anew the so-called pentathionates of potassium and baryum, and he finds these tetrathionates instead of pentathionates. $-\mathbf{M}$. van Beneden amounces the discovery of some gigantic fossil reptiles (probably Iguanodon) in the coal formation of Bernissart, near Peruwelz; and there is some correspondence between Count Du Moncel and MM. Navez on the subject of the telephone.

Reale Istituto Lombardo di Scienze è Lettere, Rendiconti, vol. xi. fasc. $x$.- -We note the following papers in this number:-Critical amnotations on duodenal anchilostoma, by Prof. Sangalli.Causes and circumstances which influence hereditary transmission in animals (continued). - Hereditary transmission in the act of fecundation; note by Prof. Lemoigne.-Cure of varicocele by means of the temporary sub-cutaneons elastic ligature, by Prof. Scarenzio.-First lines of a cardiographic study designed for clinical purposes, by S. de Giovanni.-On the electromotive force developed from saline solutions of different degrees of concentration, with metals which do not form the base, by Prof. Cantoni.-Résumé of meteorological observations at Milan, in the Royal Observatory of Brera in 1877 , by S. Fisiani, Jun.

The Fournal of the Russian Chemical and Physical Societies (vol, x. No. 6) contains the following more important papers: On the action of iodide of butyl upon isobutylene in the presence of metallic oxides, by Miss Julie Lermontoff.-On quinine and cinchonine, by $\mathrm{A}$. Wischnegradsky and $\mathrm{A}$. Boutlerow.-On the fatty acids which are formed by the action of alkali upon cinchonine, by $M$. Lubavin, - On the hexylenes resulting from tertiary hexylic alcohols, and on their condensation, by $\mathrm{L}$. Tavein.-On the preparation of bromide of trimethylene, by $\mathrm{T}$. Bogomollez.-On the structure of the hydrocarbon $\mathrm{C}_{19} \mathrm{H}_{14}$ resulting from chloride of triphenyl-carbinol, by V. Hemilian. -On the anhydride of glyceric acid, by $\mathrm{N}$. Socoloff.-On the formation of albumen from one of its products of decomposition, by A. Danilewsky. - On the action of bromine upon the compound homologues with benzol in the presence of bromide of aluminium, by $\mathrm{G}$. Gustavson.-On diallylpropylcarbinol, by $\mathrm{P}$. and A. Saytzeff.- - On the conversion of primary alcohols into ethers, by N. Menschutkin.-On the theory of the current, by P. Van der Vliet.- On the resistance of steel, by M. Picatscheff.

\section{SOCIETIES AND ACADEMIES}

PHILADELPHIA

Academy of Natural Sciences, Jantary 29.-On the mode of recognition among ants, by Rev. H. C. McCosk.--Notes on the natural history of Fort Maçon, North Carolina, by Dr. Elliot Cones and Dr. H. C. Yarrow.-Description of new invertebrate fosiils from palrozoic rocks of Illinois and Indiana, by Dr. C. A. White.

February 5.-Note on Calycanthus floridus, by $\mathrm{Mr}$. T. Meehan.

February 26. - On the alkali of the plains in Bridger Valley, Wyoming, by E. Goldsmith.-On the mechanical genesis of tooth-forms, by J. A. Ryder; an important paper on mammalian teeth.

March 26.-On the electric constitution of the solar system, by Jacob Ennis.

April 2.-On the toilet habits of ants, by Rev. H. C. McCook, -On the Basilica spider and her snare, and on the probable geographical distribution of a spider by the trade winds, by same author.-Notes on Acer rubrum, by Mr. T. Meehan.
April 6.-On the vegetative repetition of cerebral fisstres, by Di. A. J. Parker.

PARIS

Academy of Sciences, July 29.-M. Fizeau president, in the chair.-New communication on the subject of the notes on alcoholic fermentation found among the papers of $\mathrm{Cl}$. Bernard by M. L. Pasteur. M. Pasteur finds that the notes, as printed in the Revue Scientifique, are in several places incorrect; $M$. Pasteur intends to repeat Bernard's experiments. M. Berthelot made a few observations on M. Pasteur's communication. - On the variations of the intensity of currents transmitted across mediocre contacts, according to the pressure exercised upon them, by M. Th. Du Moncel.-Absorption by the living organism, of carbonic oxide introduced in determined proportions into the atmosphere, by M. N. Gréhant.--On the rôle of coal dust in the production of explosions in mines, by M. L. Simonin.-New theory of the alterations caused by the phyl loxera on the roots of the European vine, by M. Millardet. -Observations of the periodic comet of 'Tempel, made with the equatorial of the garden of the Paris Observatory, by M. Pr. Henry.-On the covariants of binary forms, by M. C Jordan. - Note on a theorem on relative movements, by $M$. Laisant. - On the non-existence of the lengthening of a conductor traversed by an electric current, independently of calorific action, by M. R. Blondlot.-New observations on the subnitrates of commercial bismuth, by M. A. Carnot.-Thermic formation of phosphoric hydrogen and of arsenious hydrogen, by M. J. Ogier.-Researches on amylic alcohol (continued) dextrogynous alcohol, by M. J. A. Le Bel.-On the identity of the inulines of various origins, by MM. Lesceur and Morelle.On the diffusion of salicylic acid in the animal economy (presence in the cephalo-rachidian liquid), by MM. Ch. Livon and J. Bernard.-On the anatomical characters of the Aye-Aye, by M. Edm. Alix.-On the influence of leaves in the production of sugar 'in beet-root, by MM. B. Corenwinder and G. Contamine.-Age of the bed of Mont Dol (Ille-et-Vilaine), by M. Sirodot.

\section{CONTENTS}

The Journal of Phystolog

A UNiversal Geograp

Russell's "Gecmetry in Modern Life, being the Substance of Two Lectures on Useful Geometry, given before the Literary Society of Eton

Cotta's "Die Giealogie der Gegenwart" "

Elwes" "Ocean and Her Rulers,",

Gray's "Under the Red Ensign",

"Memoir of the Late Alfred Smee, F.R.S." by his paut. With a Selection from his Miscellaneous Writings" LETTERS TO THE EDTTOR:-

An Intra-Mercurial Planet.-Sir G. B. Atry

Floating Magnets.-C. C. Pierce

Mons. A. Cavaille-Coll on Musical Pitch, the French Diapa Normal, Scheibler's Tuning-Forks, \&c.-Alexander J. ELLis, F.R.S. . . .

Peaucellier Cell.-HoRAcE DarwiN (with Illustration)
The Microphone--Prof. WM. LEROY BROUN; GERALD B The Microphone.-Prof. WM. LEROY BROUN; GERALD B. A Simpler Form of the Phoneidoscope- -J. E. H. Gordon

Spectrum of the Electric (Jablochkoff) Light. - E. Walker

The Meteor Showers of July.-W. F. DENNING

The Rainfall of Brazil and the Sun-spots.-ORviLit A. DEREY

The Cell of the Bee.-EDWARD GEoGHeGaN (With Illustration).

OUR Astronomical COLUMN :-

The Reported Observation of "Vulcan"

The Lunar Eclipse on August r2 .

The August Meteors.

Tempel's Comet

The Primary Germ-Layers and the Origin of the Aiale and Female Reproductive Elements, -E. R. L.

The Toilet Habits of Ants

The Mode of Recognition among Ant

The Snare of the Basilica Spider

Sexual Conditions in the Red Maple

Geographical Notes

THE Elasmotherrum (With illiusirations)

UNDERGROUND MONSTERS

Two Australian Geologists

The British Association

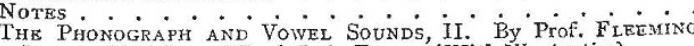
JENKIN, F.R.S., and Prof. J. A. EwING (With Illustration) . . D Expertments on the Relative Specific Gravities of Solid AND Melted Materials at the Temperature of Fuston.
Joseph Whitlex The InFluence of Ligit uTON Bioplasm. By Dr. Arthur Downes and T. P. BLUNT, M.A.

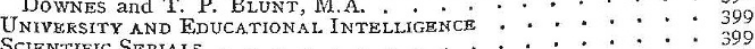

SCIENTYFIC SERIALS

SOCieties AND ÁCADEMUIS
PAGE 377

380 